\title{
Pengaruh Pemberian Tablet Fe Dan Jus Tomat Untuk Peningkatan Kadar Hemoglobin Pada Remaja SMK N 1 Mesuji Oki Sumatra Selatan
}

\author{
Jenny Anna Siauta, Wayan Anita \\ Fakultas Ilmu Kesehatan, Universitas Nasional, Jakarta, Indonesia \\ Corresponding author: Jenny Anna Siauta (jenny.siauta@civitas.unas.ac.id) \\ Received: Mei, 16 2020; Accepted: June, 15 2020; Published: September, 12020
}

\begin{abstract}
ABSTRAK
Menurut Riskesdas tahun 2013, prevalensi anemia di Indonesia yaitu 21,7\% dengan penderita anemia berumur 5-14 tahun sebesar 26,4\% dan 18,4\% penderita berumur 15-24 tahun (Kemenkes RI, 2014). Wanita mempunyai risiko terkena anemia paling tinggi terutama pada remaja putri (Kemenkes RI, 2016). Oleh karena itu dibutuhkan terobosan baru, yang bisa membantu percepatan peningkatan kadar Hb remaja, dengan pemberian Fe dan Jus Tomat. Penelitian ini menggunakan desain one group pretst- postes. Sampel diambil dengan tehnik purposice sampling dan diperoleh 30 remaja. Analisis data menggunakan analisis univariat dan bivariat dengan uji wilcoxcon. Hasil penelitian rata-rata kadar $\mathrm{Hb}$ sebelum diberikan $\mathrm{Fe}+\mathrm{Jus}$ Tomat adalah 9,973 dengan standar deviasi 0,9652, setelah diberikan Fe + Jus Tomat adalah 10,660 dengan standar deviasi 1,1944. Analisa uji bivariat, didapatkan $p$-velue $=0,000$. Ada pengaruh pemberian $\mathrm{Fe}$ dan Jus Tomat terhadap peningkatan kadar Hb remaja.
\end{abstract}

Kata Kunci: Pemeriksaan Hemoglobin, pemberian tablet Fe dan Jus Tomat

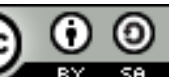

This is an open-acces article distributed under the terms of the Creative Commons Attribution-ShareAlike 4.0 International License.

\section{PENDAHULUAN}

Anemia merupakan keadaan dimana masa eritrosit dan atau masa $\mathrm{Hb}$ yang beredar tidak dapat memenuhi funginya untuk menyediakan oksigen bagi jaringan tubuh. Penurunan $\mathrm{Hb}$ dapat menyebabkan keadaan lesu, cepat lelah, palpitasi, takikardi, sesak nafas, angina pectoris (Proverawati, 2011). Anemia merupakan salah satu masalah kesehatan di seluruh dunia terutama negara berkembang yang diperkirakan $30 \%$ penduduk dunia menderita anemia. Anemia banyak terjadi pada masyarakat terutama pada remaja dan ibu hamil. Anemia pada remaja putri sampai saat ini masih cukup tinggi, Menurut World Health Organization (WHO), pada tahun 2012 prevalensi anemia dunia berkisar 40-88\%. Jumlah penduduk usia remaja (1019 tahun) di Indonesia sebesar 26,2\% yang terdiri dari 50,9\% laki-laki dan 49,1\% perempuan (Kemenkes RI, 2015).

Menurut data hasil Riskesdas tahun 2013, prevalensi anemia di Indonesia yaitu 21,7\% dengan penderita anemia berumur 5-14 tahun sebesar 26,4\% dan 18,4\% penderita berumur 1524 tahun (Kemenkes RI, 2014). Data Survei Kesehatan Rumah Tangga (SKRT) tahun 2012 menyatakan bahwa prevalensi anemia pada balita sebesar 40,5\%, ibu hamil sebesar 50,5\%, ibu 
nifas sebesar $45,1 \%$, remaja putri usia 10-18 tahun sebesar 57,1\% dan usia 19- 45 tahun sebesar $39,5 \%$. Wanita mempunyai risiko terkena anemia paling tinggi terutama pada remaja putri (Kemenkes RI, 2015).

Angka kejadian anemia di Sumatra selatan pada tahun 2013 mencapai 57,1\%. Anemia pada remaja putri masih merupakan masalah kesehatan masyarakat karena prevalensinya lebih dari $15 \%$. Angka kejadian anemia didapatkan pada balita umur 0-5 tahun sebesar 40,5\%, usia sekolah sebesar 26,5\%, Wanita Usia Subur (WUS) sebesar 39,5\%, pada ibu hamil sebesar 43,5\% (Dinkes Sumatera Selatan, 2014). Remaja putri merupakan salah satu kelompok yang rawan menderita anemia.

Remaja merupakan salah satu kelompok rentan gizi, Dikarenakan pada masa ini adalah masa yang sangat pertumbuhan yang sangat pesat. Wanita usia subur cenderung menderita anemia dikarenakan wanita mengalami menstruasi setiap bulan, dan ini akan diperberat jika asupan zat besi dari makanan sehari-hari rendah. Penyerapan besi dipengaruhi oleh banyak faktor. Protein hewani dan vitamin C meningkatkan penyerapan. Kopi, teh, garam kalsium, magnesium dapat mengikat Fe sehingga mengurangi jumlah serapan. Karena itu sebaiknya tablet Fe ditelan bersamaan dengan makanan yang dapat memperbanyak jumlah serapan, sementara makanan yang mengikat Fe sebaiknya dihindarkan, atau tidak dimakan dalam waktu bersamaan. Disamping itu, penting pula diingat, tambahan besi sebaiknya diperoleh dari makanan (Proverawati, 2011)

Berdasarkan hasil prasurvei yang dilakukan tanggal 15-20 Maret 2018, diketahui bahwa di wilayah Mesuji memiliki 4 sekolah menengah atas, dari ke 4 SMA tersebut didapatkan jumlah siswi SMA yang terbanyak yaitu 89 orang. Dari 10 remaja putri yang peneliti lakukan pemeriksaan kadar HB sebanyak 8 (80\%) remaja dengan kadar HB Kurang dari $12 \mathrm{gr} \%$ dan 2 (20\%) dengan hasil kadar haemoglobin $12 \mathrm{gr} \%$. Hasil wawancara pada remaja putri mengungkapkan bahwa tidak mengetahui bahwa Fe dan Jus tomat dapat menigkatkan kadar $\mathrm{Hb}$ dan mereka belum pernah mencoba untuk mengknsumsi bubur kacang hijau untuk mengatasi anemia.

Anemia pada remaja dapat menyebabkan keterlambatan pertumbuhan fisik gangguan prilaku serta emosional. Hal ini dapat mempengaruhi proses pertumbuhan dan perkembangan sel otak sehingga dapat menimbulkan daya tahan tubuh menurun mudah lemas dan lapar. Konsentrasi belajar terganggu prestasi belajar menurun serta mengakibatkan produktifitas kerja yang rendah. Secara umum tingginya prevalensi anemia disebabkan oleh beberapa faktor diantaranya rendahnya asupan zat besi dan zat gizi lainnya seperti vitamin A, C, folat, riboplafin dan B12 untuk mencukupi kebutuhan zat besi dalam seharinya bisa dilakukan dengan mengkonsumsi sumber makanan hewani sebagai salah satu sumber zat besi yang mudah diserap, mengkonsumsi sumber makanan nabati yang merupakan sumber zat besi yang tinggi tetapi sulit diserap (Depkes, 2013). Marida (2016) mengemukakan bahwa kombinasi daun bayam hijau dengan kandungan zat besinya yang tinggi dan tomat dengan kandungan vitamin $\mathrm{C}$ yang mempercepat absorpsi zat besi dalam tubuh dapat meningkatkan produksi sel darah merah sehingga kadar hemoglobin juga meningkat.

\section{METODE}

Penelitian ini menggunakan desain penelitian pra-eksperiment one group pre-test-posttest desain ini hanya menggunakan satu kelompok saja yaitu kelompok eksperimen tanpa kelompok kontrol. Sebelum diberikan perlakuan, kelompok eksperimen terlebih dahulu diperiksa kadar haemoglobinnya, kemudian diberikan perlakuan (treatment) berupa tablet $\mathrm{Fe}$ dan jus tomat setelah itu diperiksa kembali kadar haemoglobinnya. Sampel yang diambil dari penelitian ini adalah 30 siswa SMK N 1 Mesuji OKI Sumatera Selatan. 
HASIL

Rata - Rata kadar Hb Sebelum dan setelah Pemberian Fe + Jus Tomat Terhadap Peningkatan Kadar Hb Pada Remaja

\begin{tabular}{cccccc}
\hline $\begin{array}{c}\text { Hb sebelum dan setelah } \\
\text { pemberian Fe + Jus Tomat }\end{array}$ & Mean & SD & Min & Max & N \\
\hline Kadar HB Sebelum & 9,973 & 0,9652 & 8,2 & 11,8 & 30 \\
\hline Kadar HB Sesudah & 10,660 & 1,1944 & 8,4 & 12,8 & 30 \\
\hline
\end{tabular}

Berdasarkan hasil uji statistik, diperoleh rata-rata $\mathrm{Hb}$ remaja sebelum pemberian $\mathrm{Fe}+\mathrm{Jus}$ Tomat adalah 9,9 gr\% dengan standar deviasi 0,9652. Setelah diberian Fe + Jus Tomat rata rata kadar $\mathrm{Hb}$ diperoleh 10,6 gr\% dengan standar deviasi 1,1944, terlihat adanya peningkatan kadar HB setelah diberikan Fe + Jus tomat.

\begin{tabular}{ccccccc} 
Pengaruh pemberian FE + Jus Tomat & \multicolumn{3}{c}{ Terhadap Peningkatan Kadar Hb } \\
& \multicolumn{7}{c}{ Pada Remaja } & & \\
\hline Kelompok & $\begin{array}{c}\text { beda } \\
\text { Mean }\end{array}$ & SD & $\begin{array}{c}\text { Std. Eror } \\
\text { mean }\end{array}$ & $\begin{array}{c}\boldsymbol{P} \text { - } \\
\text { Value }\end{array}$ & $\begin{array}{c}\text { t- } \\
\text { test }\end{array}$ & N \\
\hline $\begin{array}{c}\text { Sebelum dan } \\
\text { setelah pemberian } \\
\text { Fe + Jus Tomat }\end{array}$ & $\begin{array}{c}0,686 \\
7\end{array}$ & 0,4125 & 0,0753 & 0,000 & 9,118 & 30 \\
\hline
\end{tabular}

Hasil uji bivariat didapatkan $p$ value $=0,000$ (p-value $<\alpha=0,05$ ) yang berarti ada pengaruh pemberian $\mathrm{Fe}+$ Jus Tomat terhadap Peningkatan Kadar Hb Pada Remaja di SMK N 1 Mesuji Kabupaten OKI Sumatra Selatan

\section{PEMBAHASAN}

Rata-rata $\mathrm{Hb}$ remaja sebelum pemberian Fe + Jus Tomat adalah 9,9 gr\% dan setelah mendapatkan tablet $\mathrm{Fe}$ dan jus tomat menjadi 10,6 gr\% terjadi peningkatan kadar $\mathrm{Hb}$ sebesar 0,6867 point. Análisis bivariat menunjukkan ada pengaruh pemberian Tablet $\mathrm{Fe}+$ jus tomat etrhadap peningkatan kadar $\mathrm{Hb}$ remaja. Penelitian ini sejalan dengan penelitian Fitriani dkk (2019) yang dilakukan terhadap ibu hamil trimester III. Rata-rata kadar hemoglobin sebelum mengkonsumsi jus tomat adalah 9,687 $\mathrm{g} / \mathrm{dl}$ dan sesudah pemberian jus tomat didapatkan nilai rata-rata kadar hemoglobin sebesar 11,773 g/dl.

Asupan zat besi selain dari makanan adalah melalui suplemen tablet zat besi. Suplemen ini biasanya diberikan pada golongan rawan kurang zat besi yaitu balita, anak sekolah, wanita usia subur dan ibu hamil. Pemberian suplemen tablet zat besi pada golongan tersebut dilakukan karena kebutuhan akan zat besi yang sangat besar, sedangkan asupan dari makan saja tidak dapat mencukupi kebutuhan tersebut. Makanan yang banyak mengandung zatbesi antara lain daging, terutama hati dan jeroan, apricot, prem kering, telur, polong kering, kacang tanah dan sayuran berdaun hijau (Arisman, 2010).

Tomat (Lycopersicum esculentum) merupakan salah satu sayuran kaya akan senyawa antioksidan seperti vitamin E,vitamin C, likopen, karatinoid, dan flavonoid yang penting untuk kesehatan. Selain penting untuk kesehatan mata, vitamin A juga penting untuk jumlah sel darah merah. Vitamin A membantu dalam memobilisasi zat besi untuk dimasukkan kedala hemoglobin untuk mengangkut oksigen. Mineral, tembaga dan fosfor berperan dalam memelihara kesehatan dan fungsi sel darah merah. Tembaga membantu dalam metabolisme zat besi sedangkan fosfor membantu hemoglobin dala pengiriman oksigen ke jaringan tubuh (Sumardiono S, Basri M dan Sihombing, RP, 2009)

Usia remaja merupakan usia dimana terdapat perubahan- perubahan hormonal dimana perubahan struktur fisik dan psikologis mengalami perubahan drastis. Masalah gizi yang utama yang dialami oleh para remaja diantaranya yaitu anemia defisiensi zat besi, kelebihan berat badan/obesitas dan kekurangan zat gizi. Hal ini berkaitan dengan meningkatnya konsumsi 
makanan olahan yang nilai gizinya kurang, namun memiliki banyak kalori sebagai faktor pemicu obesitas pada usia remaja. Konsumsi jenis-jenis junk food merupakan penyebab para remaja rentan sekali kekurangan zat gizi.

Menurut peneliti kadar $\mathrm{Hb}$ remaja mengalami penurunan secara umum tingginya prevalensi anemia disebabkan oleh beberapa faktor diantaranya rendahnya asupan zat besi dan zat gizi lainnya seperti vitamin A, C, folat, riboplafin dan B12 untuk mencukupi kebutuhan zat besi dalam seharinya bisa dilakukan dengan mengkonsumsi sumber makanan hewani sebagai salah satu sumber zat besi yang mudah diserap, mengkonsumsi sumber makanan nabati yang merupakan sumber zat besi yang tinggi tetapi sulit diserap.

Berdasarkan pendapat dari peneliti bahwa kebutuhan gizi remaja diperlukan, dikarenakan remaja masih dalam proses pertumbuhan, dan remaja wanita mengalami menstruasi ditiap bulannya, hal ini yang menjadi salah satu faktor terbesar remaja anemia. Apabila remaja kekurangan zat besi atau anemia dapat menggangu proses pertumbuhan dan konsentrasi belajar, remaja harus lebih peduli pada kesehatan diri sendiri, untuk mengikuti pendidikan kesehatan yang diberikan oleh tenaga kesehatan dan anjuran untuk minum tablet fe (60 mg besi elemental) 1 tablet setiap minggu sebagai upaya pencegahan anemia sesuai dengan ketetapan Peraturan Menteri Kesehatan Republik Indonesia Nomor 88 tahun 2014, karena remaja putri mengalami menstruasi disetiap bulannya, yang menjadi sebab terbesar anemia pada remaja putri. dalam hal ini petugas kesehatan dapat berperan untuk mengurangi kejadian anemia remaja dengan memberikan penyuluhan berupa asupan nutrisi yang tepat bagi remaja sehingga remaja tidak mengalami anemia, peningkatan pengetahuan remaja terhadap makanan yang mengandung zat besi tinggi terutama jus tomat dikonsumsi dapat meningkatkan $\mathrm{Hb}$.

\section{KESIMPULAN}

Berdasarkan hasil penelitian di atas, maka dapat disimulkan bahwa:

1. Rata-rata nilai kadar $\mathrm{Hb}$ remaja sebelum diberikan tabket $\mathrm{Fe}+\mathrm{Jus}$ Tomat adalah 9,973 dengan standar deviasi 0,9652 dan setelah diberikan tablet Fe + Jus Tomat adalah 10,660 dengan standar deviasi 1,1944

2. Analisis bivariat menunjukkan ada Pengaruh pemberian tablet $\mathrm{Fe}+\mathrm{Jus}$ Tomat terhadap peningkatan Kadar Hb sebesar 0,68gr\%.pada remaja di SMK N 1 Mesuji Kabupaten Oki Sumatera Selatan Tahun

\section{DAFTAR PUSTAKA}

Arisman. (2010). Buku Ajar Ilmu Gizi, Gizi dalam Daur Kehidupan. Jakarta:EGC. Depkes RI. 2013. Riset Kesehatan Dasar Republik Indonesia. Jakarta : Depkes RI Dinkes Sumatra Selatan. 2012. Profil Kesehatan Kab. OKI , 2014. Sumatra Selatan :Depkes. Fitriani F, Evayanti Y, Nurul I. 2019. Pemberian Jus Tomat Terhadap Kadar Hemoglobin Pada Ibu Hamil Trimester Iii Tahun 2019

Kementerian Kesehatan RI. 2014. Peraturan Menteri Kesehatan Republik Indonesia Nomor 88 tahun 2014 tentang Standar Tablet Tambah Darah Bagi Wanita Usia Subur dan Ibu Hamil. Kementerian Kesehatan

Kementerian Kesehatan RI. 2015. Profil Kesehatan Indonesia Tahun 2015. Jakarta : Depkes RI

Merida, et al. 2016. Efektifitas Terapi Kombinasi Jus Bayam dan Tomat Terhadap Peningkatan Kadar Hemoglobin pada Ibu Hamil dengan Anemia. Riau :Universitas Riau

Notoatmodjo, S. 2015. Metodologi Penelitian Kesehatan. Jakarta : Rineka Cipta. Proverawati, A. 2011. Anemia dan Anemia Kehamilan. Yogyakarta : Nuha Medika 
Sumardiono S, Basri M dan Sihombing, RP. Analisis Sifat-Sifat Psiko-Kimia Buah Tomat (Lycopersicumesculentum) Jenis Tomat Apel, GunaMeningkatkan Nilai Fungsi BuahTomat Sebagai Komoditi Pangan Lokal.Semarang: Universitas Diponegoro:2009 